\title{
'Let's have a song upon the gramophone': Manufactured music - records, radio and the cinema
}

Away with dull care,/The day is set fair,

A wireless set near/ To bring us good cheer!

...

In Winter time/ And Summer time,

Or leisure time/ And pleasure time,

The daily times/ That Big Ben chimes

Are radio times!

Radio Times, 'Dan Donovan with Henry Hall \& The BBC Dance Orchestra'

THE ROOTS OF the new technologies date from the late nineteenth century, but it was after the Great War that the spread of 'manufactured music' revolutionised the production and consumption of popular (and other forms of) music. In their different, though intertwined ways, the gramophone, the radio and the cinema transformed the way in which people listened to music, while greatly increasing its availability. For the listener, the dependence on the local music hall or park bandstand was reduced. Instead of enjoying a once-off, not to be repeated, live performance, she or he could listen to music broadcast on radio at certain times, or to a record of choice at any time. The gains in flexibility and scope had to be offset against losses of quality of the listening experience. Even with the advent of electrical recording in the mid-1920s the frequency ranges achievable on record were significantly less than those 
experienced in the concert hall. ${ }^{1}$ The quality of cheaper records aimed at the mass market was modest. Similarly, the quality of broadcast music was subject to technical limitations, to which musicians had to adapt. Electrical recording reduced the need to crouch round a recording horn and increased the range of instruments that could be used, thereby reducing the heavy reliance on brass bands and military music in early recordings. There were other implications for the way in which music was produced such as the time limitations of a 12-inch record. Song writers had to work within a much tighter timeframe than their nineteenth century counterparts. Similarly, the length of a radio programme influenced what could be produced. ${ }^{2}$ Nonetheless, the impact of the new technologies on popular music were far-reaching.

\section{The record industry}

Attempts at commercial exploitation of Edison's 'talking machine' in Britain dated back to the late-1870s, but it was not until the Edwardian years that major developments took place. On the eve of the Great War, there were some 500,000 'talking machines' in Britain, estimated as equivalent to one in every three houses, and some fifteen million records sold annually. By the early 1930s the number of record sales had grown by a factor of four and almost two out of three households owned a gramophone. ${ }^{3}$ Unlike the dance halls, the record industry was not recession proof. The number of acoustic gramophones available for the domestic market rose from 256,522 in 1924 to 503, 663 in 1930. Numbers collapsed in the early 1930s and, despite a rally later in the decade, the total available for the domestic market was only 40,600. Similarly, records available for the domestic market peaked at 55 million in 1930, only to fall below 20 million four years later. ${ }^{4}$ These developments took place within the context of a broader 'retailing revolution' now extending to 'luxury' items. ${ }^{5}$

Initially, the gramophone was often an outside novelty, to be heard in assembly halls, at fairgrounds or from itinerant street 'musicians,' pushing one mounted on a barrow. Portable models, in particular, appeared in a growing number of venues, some contributing to the dance boom of these years, others providing a more sedate experience of listening to music; and 
yet others, more problematically, appearing al fresco as daytrippers took to the seaside. Gradually attention shifted to an emerging mass market among the skilled and semi-skilled working classes. ${ }^{6}$ In 1935 one in six of the respondents to a readership survey of the up-market Gramophone identified as wage earners (a euphemism for working class). ${ }^{7}$ Given Gramophone's readership, this almost certainly understates the extent to which the record industry appealed across class lines, as retail prices of gramophones and records continued to fall during the 1920s. Before the war, the Winner Record Company, created with an eye to the lower end of the market, reduced the cost of its records by 40 per cent between 1912 and 1913, but at 1s $6 \mathrm{~d}$ this was still not a cheap item. Nor was a gramophone, the price of the cheapest model was equivalent to the cost of 200 tickets for the music hall. ${ }^{8}$ The 1920 s saw increased competition and falling prices, with Decca, HMV and especially EMI to the fore. More specifically, budget labels sprang up and their records were available at the new highstreet chains, such as Woolworths, Curry's and Marks and Spencer. All in all, the growing popularity of the gramophone brought popular music to an ever-widening audience.

The broad contours of consumer taste, as reflected by record sales, are clear. From the outset some music hall stars, notably Harry Champion, Harry Lauder and Florrie Forde, availed themselves of the new technology. ${ }^{9}$ The technical limitations of early recording techniques restricted the possibilities for ensembles, hence the over-representation of Sousa marches (particularly 'Washington Post and 'Liberty Bell') and von Suppé overtures (especially 'Poet and Peasant' and 'Light Cavalry'). ${ }^{10}$ From the mid-1920s onwards, the new electrical recording broadened the range. A 1930 survey showed the dominance of popular dance and vocal records (roughly 50 per cent of sales), with comic songs as popular as opera. ${ }^{11}$ Yet within these broad categories were several surprises. Among the best-selling records in the HMV/Zonophone catalogue were predictable hits - the Savoy Orchestra's 'Valencia/The Student Prince' and Gracie Fields' 'My Blue Heaven/Because I Love You' - but they were outsold by the Temple Church's rendition of Mendelssohn's 'Hear My Prayer,' which sold over 800,000 copies between its release in 1927 and $1938 .{ }^{12}$ Given 
the transatlantic reach of several big record companies, certain American performers sold well in Britain. Maurice Gunsky, an American tenor, typically singing to a piano or piano and violin accompaniment, recorded songs such as 'Ramona,' 'Let Me Call You Sweetheart' and 'Girl of My Dreams,' but his most successful record was 'Why Do I Always Remember/ Lay My Head Beneath a Rose,' which sold almost a quarter of a million copies. ${ }^{13}$ Another American, country singer Bud Billing (aka Frank Luther when not recording for Zonophone) sold over 200,000 copies of 'The Wanderer's Warning/Will the Angels Play Their Harps for Me?' both characterised by lyrics of saccharine sentimentality and banal tunes. ${ }^{14}$ Frank Crumit, another folk and novelty singer, sold well for HMVVictor and Decca, despite never visiting Britain. His greatest success came with Percy French's nonsense song 'Abdul, Abulbul Amir.'15 Whimsy was very much the order of the day. The Ben Selvin Novelty Orchestra sold an estimated half a million copies of 'Dardenella,' released in 1920, but is more remembered for 'I'm Forever Blowing Bubbles,' which has survived thanks to the tribal loyalty and singing talents of generations of West Ham United fans! In similar vein, the International Novelty Orchestra (in fact the Victor studio orchestra) had success with 'The Cuckoo Waltz' and 'The Flapper Wife' in the early 1920s, but also recorded pre-war hits such as the 1890s minstrel show song, 'After the Ball' and the sentimental 'Let Me Call You Sweetheart,' first recorded in 1910.

Popular songs were covered by various artists. By far and away the most covered song was 'Sonny Boy.' Although now associated overwhelmingly with $\mathrm{Al}$ Jolson, it was recorded at least 40 times by artists that included well-known figures, such as Paul Robeson and John McCormack as well as lesser known ones, such as Ruth Brown and Ruth Etting. Some way behind, were songs such as 'Carolina Moon.' and 'I Can't Give You Anything but Love Baby.'The popularity of the latter was enhanced by its inclusion in the Broadway revue Blackbirds of 1928 The inter-relatedness of popular musical culture is further underlined by two very successful and much-covered songs from the film Broadway Melody; the first the title song, the second, the now largely-forgotten 'Wedding of the Painted Doll,' which was covered over twenty times. ${ }^{16}$ 
Records, particularly when linked to films, were an important element in the careers of various performers who were to become household names between the wars. Dance band leaders, such as Jack Hylton, Ambrose and Jack Payne were at the forefront. Jack Payne made over 200 records for Columbia between 1928 and 1932, of which over 60 sold more than 10,000 copies, generally regarded as a measure of success at the time. 'Stein Song/Moonshine is Better Than Sunshine' sold 95,000 copies and 'When It's Springtime in the Rockies/I'm Falling in Love' over 70,000. ${ }^{17}$ Gracie Fields and George Formby, the best remembered popular singers of the time were not alone. For example, Jeanette MacDonald, first with Maurice Chevalier and later with Nelson Eddy, appeared in several films which generated such popular songs as 'Dream Lover' (from The Love Parade) and 'Indian Love Call' (from Rose Marie). ${ }^{18}$

There were also some less obvious successes. Caruso's recording of 'Vesti La Giubba' sold massively. In a lengthy career, he combined operatic extracts with Neapolitan songs, exemplified by his 1933 Victor Red Label record,'O Sole Mio/ La Donna e Mobile.' Another operatically trained singer with a long recording career and considerable popularity was John McCormack. His relationship with England was complex, culminating in his decision to seek American citizenship. Like Caruso his recorded output combined operatic extracts with popular Irish songs. His earliest recordings for Odeon (London) made between 1906 and 1909 included extracts from Rigoletto, Aida and La Boheme, sentimental Irish airs (notably 'The Snowy Breasted Pearl,' 'Kathleen Mavourneen,' 'Killarney' and 'Eileen Aroon') and unequivocally nationalist songs ('A Nation Once Again,' 'God Save Ireland' and the 'Croppy Boy'). Given the mounting tensions in Ireland at the time, it is difficult to see the latter appealing beyond (some) members of the Irish diaspora. The balance of his repertoire changed after the Great War. ${ }^{19}$ Operatic extracts continued to be recorded but the Irish element became increasingly sentimental, while overtly nationalist songs disappeared. His Victor Electric recordings (1925-31) contained songs recorded before the war -- 'When You and I Were Seventeen' and 'Kathleen Mavourneen' alongside such quintessential Irish songs as 'Mother Macree' 
and 'The Rose of Tralee' as well as the saccharine 'Ireland, Mother, Ireland.' In addition, he recorded popular sentimental songs - 'Sonny Boy,' Moonlight and Roses' and 'Silver Threads Among the Gold' - as well as older songs such as 'Annie Laurie' and even 'Who Is Sylvia?' McCormack's appeal to Irish audiences is well-known but the sanitising and broadening of his popular repertoire in the 1920s and 1930s won him a larger audience on both sides of the Atlantic.

In sum, the spread of gramophone and record ownership led to an 'unprecedented availability' of recorded music but evaluating the impact of the record industry is complicated by two factors. ${ }^{20}$ First, the data relating to record sales is incomplete and not open to simple interpretation. Given the prevalence of communal usage, the audience for any given record was greater (to an unknowable extent) than simple sales figures. Second, the impact of the record industry was intertwined, in a mutually reinforcing way, with the development of radio and film.

\section{Radio}

The expansion in radio ownership during the inter-war years was dramatic and had a profound effect on the cultural life of the nation. In the early 1920s licence holders numbered in the hundred-thousands (the precise figure is open to debate) but by the late 1930s had exceeded 9 million. As the figures in Table 1 show, the growth in the number of licence holders was dramatic, doubling in the second half of the 1920s and growing by a further factor of three in the 1930s. Improved technology - valve sets rather than crystal - and falling price underpinned the surge in ownership and the transformation from a luxury to a mass consumer good. Three out of four households, some thirty-four million people, had access to the radio on the eve of the second world war.

The most important player was the BBC but, despite its dominant position, it never enjoyed a monopoly of broadcasting. Nonetheless, the development of radio broadcasting in Britain took a significantly different form from that in America, with its proliferation of broadcasting stations. The BBC went on air in November 1922 with limited geographical coverage. Within a year eight stations had been opened, reaching roughly 50 per cent of the population, rising to 70 per cent in 1924.1925 saw 
Table 1: Broadcast Receiving Licences, 1923-39

\begin{tabular}{|c|c|c|c|c|c|}
\hline Year & No. (000s) & $\begin{array}{c}\text { Index } 1930 \\
=100\end{array}$ & Year & No. (000s) & $\begin{array}{c}\text { Index } 1930 \\
=100\end{array}$ \\
\hline 1923 & 125 & 4 & 1931 & 3,647 & 118 \\
\hline 1924 & 748 & 24 & 1932 & 4,620 & 149 \\
\hline 1925 & 1,350 & 44 & 1933 & 5,497 & 178 \\
\hline 1926 & 1,960 & 63 & 1934 & 6,260 & 203 \\
\hline 1927 & 2,270 & 73 & 1935 & 7,012 & 227 \\
\hline 1928 & 2,483 & 80 & 1936 & 7,618 & 246 \\
\hline 1929 & 2,730 & 88 & 1937 & 8,131 & 263 \\
\hline 1930 & 3,091 & 100 & 1938 & 8,589 & 278 \\
\hline & & & 1939 & 8,968 & 290 \\
\hline
\end{tabular}

Source: B R Mitchell \& H G Jones, Second Abstract of British Historical Statistics, Cambridge University Press, 1971, p.114

eleven low-power relay transmitters brought online and the high-powered longwave transmitter at Daventry. An important breakthrough was the development of the valve set, which replaced the older crystal set with its reliance on headpieces. The valve set, while not without technical limitations, was a more attractive option. As well as operating via a loudspeaker, it could amplify weak signals and distinguish more effectively between stations.

By the early 1930s the BBC's geographical coverage in England was almost 100 per cent, but there were variations in its audience. In an age before the portable transistor radio, listening habits were determined partly by family hierarchy and partly by generational differences in non-domestic leisure activities: the dance hall, particularly, and the cinema were more strongly associated with the young and single. In the late-1930s the largest segment of the BBC's audience was (by the standards of the day) middle-aged, and while it attracted significant numbers of listeners in their late teens and twenties, these age groups were appreciably more likely to listen to commercial stations.

The BBC played an important role in bringing dance music and popular song to a wide audience, but this was not 
a foregone conclusion, nor was the route straightforward. The dominant figure from the outset was John Reith. He was not simply a left-over from an earlier (Victorian) age which believed in 'rational recreation' in general and music as a force for uplifting and unifying society. ${ }^{21}$ Rather he believed such beliefs were ever more necessary in the democratising world of the early twentieth century. Universal manhood suffrage and partial (later total) female suffrage necessitated, in his eyes, the creation of a well-informed, civilized general public. Radio broadcasting, as he argued in Broadcast Over Britain, 1924, was to prioritise education over entertainment; to set high standards, including high moral standards, for all and to instil a sense of national harmony that would transcend the bitter divisions that scarred the country in the immediate post-war years. ${ }^{22}$ Through the BBC, he would impose a benign paternalism. There would be freedom - freedom of access but not freedom of choice. Translated into practical broadcasting terms, this meant, among other things, that Sundays would be strictly observed, with no concessions to frivolity, and that improving, high culture would dominate the airwaves. Not for the last time, a moral entrepreneur was to find that what the public wanted to listen to was not what he believed they should hear. There was considerable tension, if not an outright contradiction, between his desire to reach as wide an audience as possible and his determination to give them what (in his opinion) was good for them, irrespective of their preferences. Similarly, the desire to educate led in one direction while the desire to unify led in the opposite. Reith was clear in his views, but the $\mathrm{BBC}$ was not a monolithic institution cast in his image. Important figures within the corporation, such as the head of Variety and 'enthusiastic Americanizer,' Eric Maschwitz, Cecil Graves, controller of programmes, and Archie Harding, the director of programmes for the northern region, who placed great emphasis on making radio accessible to ordinary people, had alternative visions. Not surprisingly, the evolution of radio broadcasting in the inter-war years involved a series of compromises and concessions. ${ }^{23}$

Music was of paramount importance to the $\mathrm{BBC}$ and the $\mathrm{BBC}$ was also a central element in the music industry as a whole. Reith and his followers were convinced of the importance of 'serious' or 'classical' music. It was to be an important element 
in terms of hours broadcast but, more, the BBC was to be a key provider through its own symphony orchestra, (founded 1930), under the distinguished conductor,Adrian Boult; as well as through its sponsorship of the Promenade Concerts from 1927, which was the most striking manifestation of the BBC's commitment to the musical welfare of the nation. Similarly, in broadcasting 'light music', comprising light and comic opera as well as light orchestral pieces, the BBC contributed to its educative role. More problematic, because it was mere entertainment, was 'popular music,' a broad category including military bands and musical comedy as well as music hall and dance band music. ${ }^{24}$

Dance music was heard on the $\mathrm{BBC}$ from the outset. The Savoy Orpheans broadcast on three weekly slots from 1924 onwards. The creation of the $\mathrm{BBC}$ dance orchestra, initially under Jack Payne, later Henry Hall, in 1928 bore testament to the importance of 'popular' music and a determination to bring in leading practitioners. ${ }^{25}$ However, its contribution to the dance boom was limited by the BBC's programming decisions. Further, dance music as aired by the BBC had a distinctive style that grew out of the wider debate about the threat of 'Americanization.' 'Hot' music was deemed inappropriate. Hugely successful musicians, notably Louis Armstrong and Duke Ellington, were rarely heard on the BBC and even when they were it was on regional programmes. If there were to be an American influence, Paul Whiteman and his orchestra, provided an acceptable model. From the outset, BBC dance music was to be tasteful but capable of holding the attention of the passive listener. While many in the BBC eschewed popularity in favour of "what we ourselves think of our work,' Hall's emphasis on melody made him very popular with listeners, notwithstanding Melody Maker's scathing dismissal of the 'inoffensively negative' nature of his playing. ${ }^{26}$

Initially, the BBC devoted relatively little time to popular music, but this had changed by the end of the 1920s. The following tables indicate the range of BBC music output. In Table 2, under the umbrella of popular music, the largest subset was that broad category that included orchestra, bands, and small groups. It is noticeable that there was significantly more light and dance music in the regional output. ${ }^{27}$ 
Table 2: Music programme time (\%) by type $-1927-1930$

\begin{tabular}{|c|c|c|c|}
\hline Type & 1927-9 average & $\begin{array}{c}1930 \\
\text { National }\end{array}$ & 1930 Regional \\
\hline Classical (all) & 18 & 15 & 36 \\
\hline Popular (all) & 25 & 21 & 18 \\
\hline Bands etc & 13 & 7 & 20 \\
\hline Dance music & 16 & 11 & 1 \\
\hline Gramophone records & 5 & 3 & \\
\hline
\end{tabular}

* Subset of light music, comprising orchestral, band and small combination (with vocalist) Source: Adapted from A Briggs, The History of Broadcasting in the United Kingdom, Volume 2, Oxford University Press, 1995, pp.34-5

The following figures, though not strictly comparable, show a relative decline in the amount of programme time given to dance music. Although there was a sharp increase in airtime for gramophone records in the 1930s, this was a broad category that also included classical and light classical music.

Table 3: Music programme time (\%) by type - 1934,1936 \& 1938

\begin{tabular}{|c|c|c|c|c|c|c|}
\hline Type & $\begin{array}{c}1934 \\
\text { National }\end{array}$ & $\begin{array}{c}1934 \\
\text { Regional }\end{array}$ & $\begin{array}{c}1936 \\
\text { National }\end{array}$ & $\begin{array}{c}1936 \\
\text { Regional }\end{array}$ & $\begin{array}{c}1938 \\
\text { National }\end{array}$ & $\begin{array}{c}1938 \\
\text { Regional }\end{array}$ \\
\hline Classical & 17 & 15 & 20 & 15 & 18 & 17 \\
\hline Popular & 29 & 43 & 22 & 39 & 23 & 32 \\
\hline Dance & 9 & 10 & 9 & 8 & 5 & 9 \\
\hline Records & 8 & 10 & 11 & 9 & 7 & 12 \\
\hline
\end{tabular}

Source: Adapted from A Briggs, The History of Broadcasting in the United Kingdom,

Volume 2, Oxford University Press, 1995, pp.49 \& 52

Differences of opinion over the balance between the two broad categories of 'serious' and 'popular' music to be broadcast on 
the BBC was not simply an internal debate, but was influenced by the competition from commercial stations broadcasting from Europe. Radio Normandie and Radio Lyon both started transmitting in 1924, followed by Radio Toulouse in 1928. The best-known and most heavily subscribed rival was Radio Luxembourg, which was on air from 1933 onwards. Prerecorded programmes, including 'hits' of the day, were shipped to the continent for broadcast back to Britain, aimed at a key demographic (the young) poorly catered for by the BBC, particularly on Sundays.

'Light' music for the BBC was a catch-all category that embraced a range of music from light classical pieces played by orchestras as well as military and brass bands, operettas and musical comedy, dance music and popular song, which, itself could range from light classical pieces, older music-hall numbers and newer songs of the day. The compromise that emerged by the mid-1930s brought together older songs, such as 'Love's Old Sweet Song,' and pre-war music-hall favourites, that provided a nostalgic appeal to an older audience and present-day hits, such as 'Sing, Gypsy, Sing' and 'Little Man You've Had a Busy Day', appealing to a younger audience. In addition, and acknowledging a Reithian duty to improve, there were 'gems' from the classics, including fantasias on folk songs, country dances, and sea songs, which combined elements of 'high' and 'low. ${ }^{28}$ Much of the music came via outside broadcasts from London hotels to seaside resorts. ${ }^{29}$

According to a Daily Mail ballot of over a million readers in 1927, the four most popular forms of 'light' music were variety and concert parties (19 per cent), light orchestral music (14 per cent), military bands (13 per cent) and dance music (10 per cent). In comparison, opera and operetta was ranked eighth (5 per cent) while at the bottom were choruses and sea shanties and chamber music (2 per cent).$^{30}$ Such expressions of public preference fed into the internal BBC debate between those in favour of leading and improving popular taste and those who believed in following popular opinion. The creation of a Revue andVaudeville Section (1930), and the subsequent airing of series such as Songs From the Shows, Music Hall, and The Kentucky Minstrels, was evidence of the BBC's awareness of the need to offer a broad range of entertainment. The establishment of a 
Listener Research Department under Robert Silvey in the mid1930s further underlined the growing sensitivity to listeners' opinions. Silvey's research confirmed the strength of popular preference for variety (93 per cent), military bands (72 per cent), and dance music (65 per cent) and light music (62 per cent). ${ }^{31}$ Listener responses also pointed to a number of (contradictory) shortcomings - too much dance music, too little dance music, poor quality dance music, and so forth - but the greatest number of complaints related to Sunday broadcasts and the total absence of light music. This presented an opportunity to the commercial stations broadcasting from the near continent. A 1937 Listener Research Department survey found a fifth of respondents listened to commercial stations during the week, rising to two-thirds on Sunday. Not all commercial stations were truly national in coverage. Radio Luxembourg came closest, but Radio Normandie struggled to get beyond London and the south of England while the Poste Parisien signal was strongest in the north of England. There were also regional variations in the popularity of specific stations, but it was clear that, taken as a whole, they appealed particularly to working and lowermiddle class audiences, women more than men and the young rather than the old. ${ }^{32}$ Unsurprisingly, popular music as a general category predominated, accounting for around 90 per cent of their airtime. In January 1937 popular songs accounted for 29 per cent of airtime, followed by light orchestral music ( 22 per cent), dance music (19 per cent), and comedy songs (15 per cent). ${ }^{33}$

Commercial station programmes had to be pre-recorded but, more importantly, this necessitated close links with the developing record companies, notably EMI and Decca. The stations, through their advertisers, made themselves more popular through association with celebrity big names. Radio Normandie, for example, offered The Rinso Radio Revue, with, among others, Jack Hylton and His Band, and The Kraft Cheese Show with Billy Cotton and his band. The response of George Formby and his fans to his appearances on The Feenamint Laxative Show is not recorded. ${ }^{34}$ In retrospect, the challenge to the BBC in the 1930s appears overstated, but, at the time, it was seen to be serious when the practice of terminating (or threatening to terminate) contracts was not working and 'stars' moved to commercial stations. Although 
this conflict would continue into the 1960s, even a generation earlier the BBC was forced to give ground and modify its light music programming. However, one thing was clear: radio in its entirety was a major force in the popular music industry and played a central role in broadening accessibility and the range of popular music.

\section{Cinema and the musical}

The third element in this process of expansion of popular, mechanical music was the cinema. Prior to the Great War cinema had been little more than a novelty turn in a variety hall programme. Within a very short period of time the cinema emerged as a major threat to variety theatre. It shared the attractions of the dance hall - opulence and escapism but on a larger scale. Spectacular epics, literally with casts of thousands, slap-stick comedy, often as daring as it was funny, romances, set in exotic locations with even more exotic stars, and even the fascinating novelty of documentary or semidocumentary films provide a ready explanation for its success. ${ }^{35}$ A further element was the musical delights offered on screen. The 'all singing, all dancing' film arrived relatively late on the scene for obvious technical reasons. However, the possibilities of portraying dance on screen was realised from the outset. Initially short films simply depicted a well-known dancer, for example Annabelle Moore in Annabelle Butterfly Dance, (1894) ${ }^{36}$ A more elaborate approach was adopted in The Whirl of Life, (1915) which told the story of the renown dancers Irene and Vernon Castle but was essentially a vehicle to show off their dances, including the foxtrot, one-step and the Castle Walk. ${ }^{37}$ In other films dance scenes were incorporated into a broader (though often flimsy) story, as in the 1910 Danish film, Afgrunden (The Abyss), which starred Asta Nielsen. ${ }^{38}$ Filmed versions of plays or operettas also offered the opportunity to incorporate dance. Salomé (1923) featured Alla Nazamova and The Dumb Girl of Portici (1916) showcased Anna Pavlova. ${ }^{39}$ Less common, but as with Valentino's tango in The Four Horsemen of the Apocalypse and, most notably, 'Maria's dance' (performed by Brigitte Helm) in Metropolis, dance was incorporated into and developed the central thrust of the film, the latter, combining in a nightmare scene, the erotic and the macabre. ${ }^{40}$ 
Various attempts were made to combine music and film. An interesting intermediate position was seen in Walter Forde's You'd Be Surprised, a 1930 musical comedy in which synchronised songs and music were added. From 1930 onwards a huge number (200 or more) of musical shorts, musicals, musical comedies and musical melodramas were produced in Britain. In addition, there were a growing number of American musicals, albeit partly constrained by the 1927 Cinematograph Film Act. ${ }^{41}$ In cinematic, and indeed musical, terms, the quality of these films varied considerably, but the increased availability of popular music is more important. The 're-discovery' of old music hall stars - Veterans of Variety led to the production of several musical shorts. Among the best known 'veterans' was Gus Elen, who came out of retirement and, at the age of sixty-nine, and recorded for Pathe three of his best known songs - 'It's A Great Big Shame,' 'Arf A Pint of Ale' and 'A Nice Fine Day' a.k.a.'The Postman's Holiday." ${ }^{\text {'T }}$ The scale and popularity of these shorts should not be underestimated. Between 1936 and 1939, British Lion released twnty-eight 9.5mm optical sound films as 'one-reelers,' with a running time of eight or nine minutes. ${ }^{43}$ Each short contained three or four acts. Typically, Variety Number 25 (November 1938), featured Reggie Bristow and His Band, playing 'Stay Out of My Dream,' Phyllis Stanley, singing 'That's My Home,' Pamela Grey and Pat Green, singing and dancing to 'This Is The Rhythm for Me' and a drum solo by Teddy Brown to 'Star Spangled Banner.'44 Bristow appeared in eight of these shorts, with only Joe Loss and his orchestra featuring more often.. Other popular (but now largely unknown) turns were the Three Accordion Kings, the Three Radio Rogues, the Petite Ascots (dancers) and the Six Lady Harpists. And this was but the tip of an iceberg that included over one hundred shorts and newsreels of the 1930s featuring dance bands. Predictably big names, such as Ambrose, Jack Hylton and Joe Loss appeared several times but there were a range of lesser-known performers who appeared on screen: Sydney Kyte and His Band, Geraldo and His Gaucho Tango Orchestra, and Ruby Bruneau and the Hawaiian Islanders,

Not dissimilar were the musical comedy shorts produced by Monty Banks in 1930, which were about half an hour long with flimsy story lines. In The Musical Beauty Shop, the beauty salon owner puts on a cabaret. This pointed to one of the most used format - the 'parade of stars,' which was used throughout 
the decade from Elstree Calling (with nineteen acts, compered by Tommy Handley) in 1930 to Calling All Stars, in 1937 and Music Hall Parade of 1939. Story lines were contrived, and the film was effectively a night at variety theatre on film. Despite their cinematic shortcomings, these films, running to eighty minutes or more, brought to the scene a range of performers who would never have been seen 'live on stage' in most towns and even some smaller cities. Even much-derided 'quota quickies,' such as Stepping Stones (1931) and Sing As You Swing (1937) featured various music-hall stars of the day, while Music Hall (1934) featured the ubiquitous G H Elliott. A variation on this theme was to focus more clearly on individuals, (such as Jessie Matthews in It's Love Again (1936) and Head Over Heels, (1937) or Jack Buchanan in Goodnight Vienna (1932). Couples such as Jack Hulbert and Cicely Courtneidge, starred in Happy Ever After (1932) and then there was The Crazy Gang in Okay for Sound (1937).

Another common device was to adapt an operetta or an opera (A Southern Maid, 1931 and Carmen,1932), a stage musical (The Maid of the Mountain, 1932) or a novel (The Girl from Maxim's and Good Companions, both 1933), though the formula did not guarantee success. The expensively produced Pagliacci, starring Richard Tauber was a flop. Exotic locations helped, from the far east (Chu Chin Chow, 1934 and The Mikado, 1939) to central Europe, particularly Vienna (notably Goodnight Vienna, 1932 and Blossom Time, 1934), though a similar effect could be achieved with a make-believe setting, such as Ruritania (The Prince of Arcadia, 1933). The effect could be further enhanced by the inclusion of an exotic stranger the Hungarian gypsy in Blue Danube (1932) or the ex-French Foreign legionnaire turned singer in the revue-style The Song of Soho (1930), though the latter was thoroughly rubbished by Monthly Film Bulletin, which thought 'the performances are poor, some of the turns vulgar, the photography bad and the film as a whole dreary. ${ }^{45}$ Finally, and not for the first (or last) time, musical films were set in a romanticised Ireland, as exemplified by Kathleen Mavourneen, (notable for being one of Maureen O'Hara's earliest films). The Minstrel Boy and The Rose of Tralee (all released in 1937) and The Mountains of Mourne and My Irish Molly (both 1938). Story lines were clichéd Irish emigrant to America returns to Ireland to find family 
- and the films little more than vehicles for well-known Irish songs. 'Danny Boy' and 'Off to Tipperary in the Morning', both featured in Kathleen Mavourneen.

The judgements of film critics are not to be dismissed lightly but there is a significant, if not always measurable, difference between critical and popular acclaim. Undoubtedly, some of these films were awful and not well received by audiences across the country, but the fact remains that the various British musical films of the 1930s brought to the local screen an amazing array of stars. Band leaders and their orchestras, such as Henry Hall, Ambrose, Carroll Gibbons, Nat Gonella and Harry Roy, appeared in numerous films; so too did older music hall stars, such as Harry Lauder, George Robey and Vesta Victoria; new stars, not just Fields and Formby but also Jack Buchanan, Jessie Matthews, Cicely Courtneidge and Jack Hulbert could be seen; so too could up-and-coming stars, such as Anna Neagle, and foreign singers including the African-American bass, Paul Robeson, the Polish tenor, Jan Kiepura, the Hungarian soprano, Gilla Alper and the American tenor, Franco Foresta. Even the English bass-baritone, Keith Falkner, better known for his concert performances, could be heard on film. Given the popularity of cinema and the range of musical performers to be seen and heard, this was a significant contribution to the dramatically expanding availability of popular music in the inter-war years. Further, the inter-relationship between the new technologies, records, radio and film, was mutually reinforcing and helped to sustain more traditional variety theatre.

The most spectacular musical films of the 1930s came from America. The impact of such films as 42nd Street and Footlight Parade or the various Gold Digger films was considerable. ${ }^{46}$ The sheer scale, the complex and stunning choreography, the innovative camera work and the array of talent put them in a class of their own. The dazzling dancing skills of Fred Astaire and Ginger Rogers featured in nine RKO films, including Top Hat, Swing Time and Shall We Dance. Although the cinemagoer was as much a passive recipient as the radio listener, the American 'all singing, all dancing' movie provided an unrivalled audio and visual experience, which showed up the limitations of their British rivals. She Shall Have Music, released in 1935, starred Jack Hylton in a clichéd story of a 
radio broadcast from a cruise ship. The film contained several instrumentals, including 'The Band that Jack Built' and 'Sailing Along on a Carpet of Cloud;' novelty songs, such as 'Why Did She Fall for the Leader of the Band? and 'May All Your Troubles Be Little Ones;' and an array of dancers that included the Leon Woizikowsky Ballet, the Dalmora Can-Can Dancers, Carmora - Spanish Dancing Beauty; Harlem's Hottest Hoofers and even the exotic dancer, Matheu Merryfield. But, like other British musicals, it failed to match the spectacle of its American rivals. ${ }^{47}$ Even The Lambeth Walk, the 1939 version of Me and My Girl, failed to get beyond the statically shot stage production. The film was largely faithful to the original, though a new street scene was added and, surprisingly, the number of songs reduced to two: 'Me and My Girl' and 'The Lambeth Walk.' Its naïve message of cheerful cockneys and understanding aristocrats coming together chimed with wartime sentiment, but parodies, particularly those featuring Hitler, proved even more popular. ${ }^{49}$

\section{Some concluding observations}

The novelty of 'mechanical' music in its various forms has rightly caught the attention of historians. The inter-war years, with their increased range and accessibility of popular music, in its various forms, witnessed a fundamental transformation in production and consumption. However, two important qualifications need to be made. First, the impact of the new technologies was limited in the 1920s. Important groundwork was done but, for example, it was not until the mid-1930s that radio became 'something that anyone could operate, offering good quality sound and interference free reception. ${ }^{50}$ The breakthrough 'Band Show' was first aired in January 1938 and even the upsurge in film musicals only started around 1930. Second, there was an important, though unspectacular, continuity in more traditional forms of music making. Piano sales may have declined, but there were plenty of 'joannas' in pubs, clubs and homes that remained the centre of sing-songs. Itinerant musicians and singing and dancing in the street may have diminished but did not disappear over-night. Indeed, communal singing received a boost in these years, as will become apparent as we turn to the songs of the 1920s and 1930s. 


\section{Endnotes}

1 See R Pearsall, Popular Music of the Twenties, Newton Abbott, David \& Charles, 1976 who claims that electrical recording increased the frequency range from 168-2000 cycles to $100-5000$ cycles, compared with the 2020,000 range experienced in a concert hall, p.100

2 Henry Wood reduced 'The Flying Dutchman Overture' from over ten minutes to less than eight. He performed a similar masterpiece of compression on Dukas's 'The Sorcerer's Apprentice.' Pearsall, Popular Music, p.94.

3 P Martland, Recording History: The British Record Industry, 1888-1931, Plymouth, Scarecrow Press, 2013, p.xviii

4 Figures from interwar UK Censuses of Production in J Nott, Music for the People: Popular Music and Dance in Interwar Britain, Oxford University Press, 2002, p.16 and p.18

5 See W Hamish Fraser, The Coming of the Mass Market, 1850-1914, London, Macmillan, 1981, J Benson, The Rise of Consumer Society in Britain, 18801980, London, Longmans, 1994 and P Gurney, The Making of Consumer Culture in Modern Britain, London, Bloomsbury, 2017.

6 Martland, Recording History, p.73 and p.77

7 Gramophone, September 1931 cited in Nott, Music for the People, p.34

8 J Mullen, 'Experiencing music in the home in Britain, 1900-1925.' Paper given to Expert Workshop, From Parlour Sing-songs to Iplayers: Experiencing culture in the 20th and 21st century homes, University of Lincoln, May 2014 at https://www.academia.edu/7143472/_PDF_full_text_ Experiencing_music_in_the_British_home_1900_1925

9 The revival of interest in old-style music hall in the late 1920s and early 1930s saw several singers taking advantage of the new electrical recordings. Columbia and Regal recorded Florrie Forde (1929), Ella Retford (1930), Harry Champion and Vesta Victoria (1931), Charles Coburn (1932) and Billy Merson (1933).

10 This element of 'middle brow' music continued after the Great War. Indeed, Stokowski and the Philadelphia Orchestra sold some 170,000 copies of Liszt's 'Hungarian Rhapsody No.2.'

11 Merchandising Survey of Great Britain figures cited in Martland, Recording History, pp.308-9

12 Martland, Recording History, p,310

13 Martland, Recording History, p,310 'Lay My Head' can be heard at https:// www.youtube.com/watch? $\mathrm{v}=\mathrm{aSOazB} 31 \mathrm{a} 5 \mathrm{w}$

14 The wanderer, having been thrown out by his father for gambling and drinking, exhorts the listener 'don't break your dear mother's heart.' A version of 'Will the Angels' by Frank Luther and His Pards can be heard at https:// www.youtube.com/watch?v=VPBMfXvi_EU Billing was probably best known for 'Barnacle Bill the Sailor.'

15 This can be heard at https://www.youtube.com/watch?v=Lv6M2omQ_U

16 See https://www.youtube.com/watch? $\mathrm{v}=$ YOOutukmhtw for the (black and white) film version, complete with Zanfield Dolly Girls. and https://www. youtube.com/watch?v $=x m v-E u Y I m-M$ to hear Ran Week's version. It was 
also recorded by Jack Hylton and later became a staple in the repertoire of Reginald 'Mr Blackpool' Dixon and his theatre organ.

17 Martland, Recording History, p.323

18 'Dream Lover' can be heard at https://www.youtube.com/watch? $==$ M3P2o5AowA and 'Indian Love Call' at https://www.youtube.com/ watch?v=1n_bUSywN94 MacDonald was a versatile singer with recordings varying from operatic extracts (from Verdi, Puccini and Gounod) to hymns such as 'Abide With Me.'

19 McCormack recorded several songs as part of the war effort, including 'Tipperary, 'Roses of Picardy' and 'When Pershing's Men Go Marching Into Picardy'

20 The phrase is Nott's, Music for the People, p.32

21 See D Russell, Popular music in England, 1840-1914, Manchester University Press, 1987, Part 1

22 For a clear and concise introduction see K Laybourn, Britain on the Breadline, Stroud, Sutton, 1998

23 For differing interpretations see J Richards, Cinema and Radio in Britain and America, 1920-60, Manchester University Press, 2010 and P Scannell \& D Cardiff, A Social History of British Broadcasting, Oxford, Blackwell, 1991, p.212

24 S Bernard, On the Radio: Music radio in Britain, Milton Keynes Open University Press, 1989, p.8

25 The appointment of Henry Hall was an important development. As well as his musical abilities, he was well informed about musical tastes outside London.

26 Bernard, On the Radio, p.15, Melody Maker quoted in P Scannell \& D Cardiff, A Social History of British Broadcasting, p.210. Hall gave his audience what they wanted to a much greater degree than Ambrose or Jack Hylton.

27 For a fuller discussion see A Briggs, The History of Broadcasting in the United Kingdom, volume 1, The Birth of Broadcasting, 1896-1927, volume 2, The Golden Age of Wireless, 1927-1939, Oxford University Press, 1995

28 Scannell \& Cardiff, Social History, 1991.

29 See for example the Savoy Orpheans, Henry Hall and the Gleneagles Hotel orchestra and Jack Payne and the Hotel Cecil orchestra.

30 Briggs, Golden Age of Wireless, p. 67

31 Cited in Richards, Cinema and Radio, p.38. In comparison were the figures for grand opera (21 per cent), violin recitals (19 per cent) and chamber music (8 per cent).

32 Further details are given in Nott, Music for the People, 72-4

33 Nott, Music for the People, p.75. In certain areas there were significant variations. Comedy songs were much more common on Poste Parisien, dance music more frequent on Radio Luxembourg and light orchestral music on Radio Normandie.

34 Nott, Music for the People, p.79

35 Richards, Cinema and Radio provides a good overview.

36 This can be seen at https://www.bing.com/videos/search?q=Annabelle + Butterfly + Dance $\&$ docid $=608043287117497300 \& \mathrm{mid}=$ 67819BE48B070119585767819BE48B0701195857\&view $=$ detail\&FORM=VIRE See also the Lumiere brothers very short clip, 'Danse Serpentine' from 1896. Some shorts were more comedic, such as the 
French 'Le Cochon Danseur' 1907 at https://www.bing.com/videos/ search?q=dansing + pig + film\&docid $=608015296822906831 \& \mathrm{mid}=4 \mathrm{D}-$ 6BAA39B04CB313BA404D6BAA39B04CB313BA40\&view $=$ detail\&FORM=VIRE. Dance was used for comedic purposes by Laurel and Hardy, 'That's My Wife,' Buster Keaton, 'The Cook' and even Charlie Chaplin's bread roll dance in 'The Gold Rush.'

37 At https://www.bing.com/videos/search?q=whirl+of+life + castle + walk\&ru $=\% 2$ fvideos $\% 2$ fsearch $\% 3 \mathrm{fq} \% 3 \mathrm{~d}$ whirl $\% 2 \mathrm{bof} \% 2 \mathrm{blife} \% 2 \mathrm{~b}-$ castle\%2bwalk\%26FORM\%3dHDRSC3\&view =detail\&mid=CFBF1806593EA1857427CFBF1806593EA1857427\&rvsmid=DFED7F670C893914E3BBDFED7F670C893914E3BB\&FORM=VDQVAP

38 At https://www.youtube.com/watch?v=2jPI9Ujjd9A See also the German, 'Pandora's Box' (1929) which allowed the former Ziegfeld Folly dancer, Louise Brooks, to show off her skills and the American 'Our Dancing Daughters' (1929), which did the same for Joan Crawford

39 'Salomé' was based on the Oscar Wilde play (see https://www.youtube.com/ watch? $=44$ OmwMoGWfs) and 'The Dumb Girl of Portici' (see https:// www.youtube.com/watch?v=D-UtUiofa8U) was based on Auber's opera.

40 Valentino can be seen at https://www.youtube.com/watch?v=C4ELzf0u7Q8 and Helm at https://www.youtube.com/watch?v=pJWhaRz7_VA

41 See S Guy, 'Calling All Stars: Musical Films in a Musical Decade' in J Richards, ed., The Unknown Thirties: An Alternative History of the British Cinema, 1929-1939, London, I B Taurus, 2000, pp.99-118

42 The films (PT85, PT96 and PT119 can be seen at https://www.britishpathe. com/video/gus-elen-3

43 http://www.pathefilm.uk/95flmdance.htm

44 https://www.youtube.com/watch?v=5KDazFVqJoI Several otherVariety Numbers are available on YouTube

45 Monthly Film Bulletin, December 1936, p.214 cited in Guy 'Calling All Stars' at p.103.

46 https://www.youtube.com/watch?v=mwuuqBVECkw from 'Gold Diggers of Broadway' and https://www.youtube.com/watch?v=mxPgplMujzQ from 'Swing Time'

47 Pathescope released a 15-minute compilation of music clips from the film in 1936. See https://www.youtube.com/watch? $=$ im36di00L6Y

48 Richards, Unknown Thirties, p.110-11

49 For example, https://www.youtube.com/watch?v=gYdmk3GP3iM

50 Scannell \& Cardiff, Social History, p.358 